\title{
Coral and Reef Fish in the Northern Quirimbas Archipelago, Mozambique - A First Assessment
}

\author{
Nicholas A. O. Hill', Johnston Davidson², Isabel Silva³, Santos Mucave, Lara Muaves , Almeida \\ Guissamulo ${ }^{6}$, Alison Debney ${ }^{7}$ and Julie Garnier ${ }^{7 *}$ \\ ${ }^{1}$ Institute of Zoology, Zoological Society of London, Regent's Park, London NWI 4RY, UK; ${ }^{2}$ Australian \\ Institute of Marine Science, Townsville, QLD 4810, Australia $;{ }^{3}$ Maluane, Av marginal, Zona de Inos, Bairro \\ Natite, Pemba, Mozambique; ${ }^{4}$ Universidade Eduardo Mondlane, Praça 25 de Junho, C.P. 257, Maputo, \\ Mozambique; ${ }^{5}$ World Wildlife Fund Mozambique, Rua D.João IV, 213, PO4560, Maputo, Mozambique; \\ ${ }^{6}$ Museu de Historia Natural, Praça da travesia do Zambeze, 104, Maputo, Mozambique; ${ }^{7}$ Conservation \\ Programmes, Zoological Society of London, Regent's Park, London NW1 4RY, UK
}

Keywords: East Africa, Mozambique, coral reef, conservation, community-based, reef surveys

\begin{abstract}
In recent years there has been much interest in the conservation and tourism value of the Quirimbas Archipelago, Mozambique. Historically, biological and conservation work has been focused on the more accessible southern part of the Quirimbas. This paper is a contribution to the knowledge on the resources in the north of the Quirimbas following survey work conducted around Vamizi Island in 2001, 2003 and principally in 2006. The results indicate it may be one of few examples in the region that has not yet suffered the same level of anthropogenic or natural disturbances that other areas in the region have suffered. Anthropogenic impacts are low as a result of its remote location that has kept it relatively isolated from markets. Limited evidence of bleaching mortality indicates that the area may have some resilience to bleaching events. Given its condition and strategic location, we suggest the area is of high conservation and research interest, and is an important economic resource that if managed wisely can contribute to sustainable fisheries and development through tourism. Threats include high levels of immigration, improved access to markets and technology, and oil and gas exploitation. The main recommendation emerging from the study is that the area is in need of timely management and formal protection.
\end{abstract}

\section{INTRODUCTION}

An estimated 22 million people live in the coastal region of East Africa, growing at a rate of 5-6\% per annum and predicted to reach 39 million by 2014 (Obura et al., 2004). Dependence on marine resources is high, with $21.6 \%$ of animal protein in Mozambique derived from fish, although this is regarded as heavily underestimated (Walmsley et al., 2006). Generally, 30-40\% of people in coastal communities fish for a living in the Western Indian Ocean, reaching up to $80 \%$ in the Quirimbas Archipelago (Loper et al., 2008). The rapidly growing demand for fish associated with high population growth has led to the degradation of reefs in East Africa, together with associated effects such as increased pollution and sedimentation, and bleaching which, in the 2004 event, caused declines in $30 \%$ of the region's reefs (Obura et al., 2004). Reefs classified as at risk in East Africa vary from $76 \%$ in Mozambique to $99 \%$ in Tanzania (Obura et al., 2004). Coastal fisheries in much of East Africa were estimated to be nearly or fully exploited as early as 1997 (Ngoile \& Linden, 1997). This decline is likely to hit the poorest sectors of society hardest, which are often among the most dependent on reef resources (Béné, 2003), and as such has caused concern for people's livelihoods (Payet 
$\&$ Obura, 2004). The sustainable management of small-scale fisheries is thus an important tool to assist with poverty reduction strategies in the region (Tobey \& Torell, 2006; Walmsley et al., 2006)

The objective of this report is to contribute to the gap on the knowledge of marine resources in the north of the Quirimbas Archipelago by reporting on the results of work conducted around Vamizi Island, and to demonstrate the potential conservation importance of this unknown area and identify threats to its current condition. The southern half of the Quirimbas Archipelago has been exposed to some level of scientific attention, all of which highlights the diversity and value of this area (e.g. Whittington et al., 1998; Pereira et al., 2003). Much conservation work has also been targeted at the southern Quirimbas, mainly with the development of the Quirimbas National Park. Based on the excellent marine resources there, there has been rapid development of a number of tourist lodges attracting guests from Europe and the USA. In contrast to the southern Quirimbas, there is no published information available on the coral reefs of the northern Quirimbas.

The Maluane initiative was developed to ensure the sustainable conservation and development of this unique area. It consists of a partnership between private sector (a tourist lodge), local communities and a conservation organisation (at the time of the surveys this was the Zoological Society of London, ZSL). The tourism operation consists of a high-end lodge with 10 spacious villas, catering for a maximum of 24 guests at any time. Prices can be as high as US\$750 per night. All guests must pay a conservation and community development bed-levy of US\$20 per night, and diving is offered for an extra fee. ZSL/ Maluane initiated the first marine scientific surveys in the northern Quirimbas Archipelago. This report represents a start at filling the knowledge gap for this area by providing information on the fish and coral communities around Vamizi Island, and identifies the conservation, management and research requirements for the area.

\section{MATERIALS AND METHODS}

\section{Site description}

Vamizi Island lies in the far north of the Quirimbas Archipelago, a continuous chain of 32 islands and several reef complexes stretching for approximately $200 \mathrm{~km}$ up the coast to the Mozambican / Tanzanian border. Vamizi Island (figure 1) lies in the north of the Archipelago. It is approximately $12 \mathrm{~km}$ long and $2 \mathrm{~km}$ wide, with the long-axis running

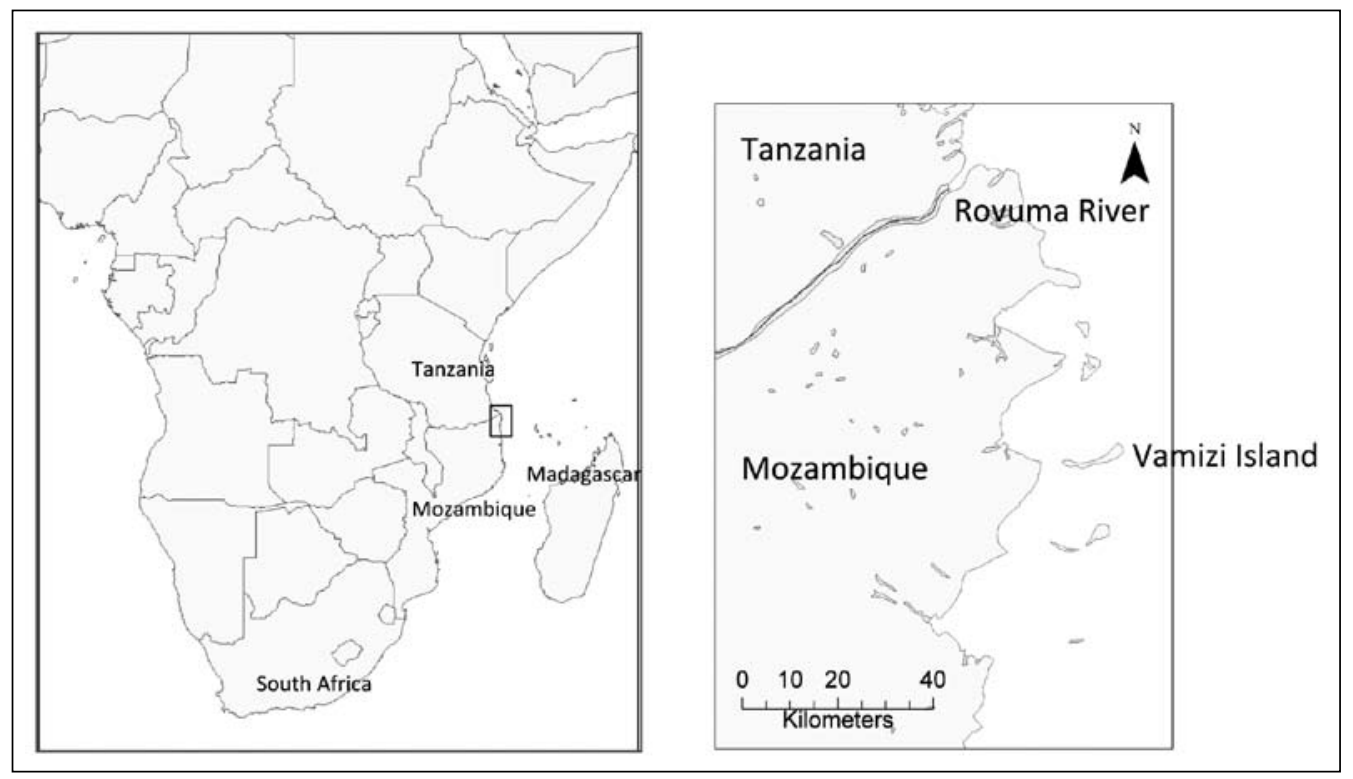

Fig. 1. Map of Africa showing the location of Vamizi Island in the Quirimbas Archipelago in northern Mozambique 
approximately east-west, lying $4 \mathrm{~km}$ from the mainland at its closest point.

There are three human settlements on the west end of the island (figure 2), all of which are predominantly fishing communities. Two of these communities consist of transient fishers from further south in Mozambique and from Tanzania, who are solely fishers. One is a resident community that also conducts limited subsistence agriculture (Hill, 2005). The two transient communities have only become permanently established in the four to five years prior to 2006, and have grown rapidly in that time. In 2003, the total population size was 533 (Garnier, 2003). In 2007 this figure had reached 1,083 (Instituto Das Pescas de Pequena Escala, pers. comm.). These people come from further south in Mozambique and from Tanzania and include fishers and traders (Hill, 2005).

Historically, and up until the time of the survey, the majority of fish caught is sold dried and for the same low price, irrespective of species (Hill, 2005). However, as recently as 2005 these new traders have started bringing cool-boxes to buy fresh lobsters and octopus (Hill, personal observation). Resident fishers from Vamizi identified the rates of immigration and the associated gears as one of the main threats to the catch rates of fishers (Garnier 2003; Hill, 2005). The two transient fishing villages only became permanent settlements on the island in the last few years. Both of these are now much larger than the original community, creating some tensions between the communities (personal observation). During the 2006 survey, the first motorised fishing boat was observed in the fishing villages. Before this point, all fishing boats were either sail-powered dhows or dug-out canoes.

There are very few employment opportunities in the surrounding area, with only one private formal employer, a tourism organisation. Levels of education are low with a single school on Vamizi that offered only one year of education in 2003 and two years in 2005. Illiteracy rates are correspondingly high (nearly $100 \%$ in women). The predominant language is Kimwani, but Kiswahili and Kimacuha are widely spoken.

The island is bounded by bathymetric intrusions to the north, south and east, providing proximity to the deep water of the Mozambique Channel. This deep water is separated from the sandy lagoon by a coral reef. On the west side of the island, shallow sandy habitat separates the island from the mainland.

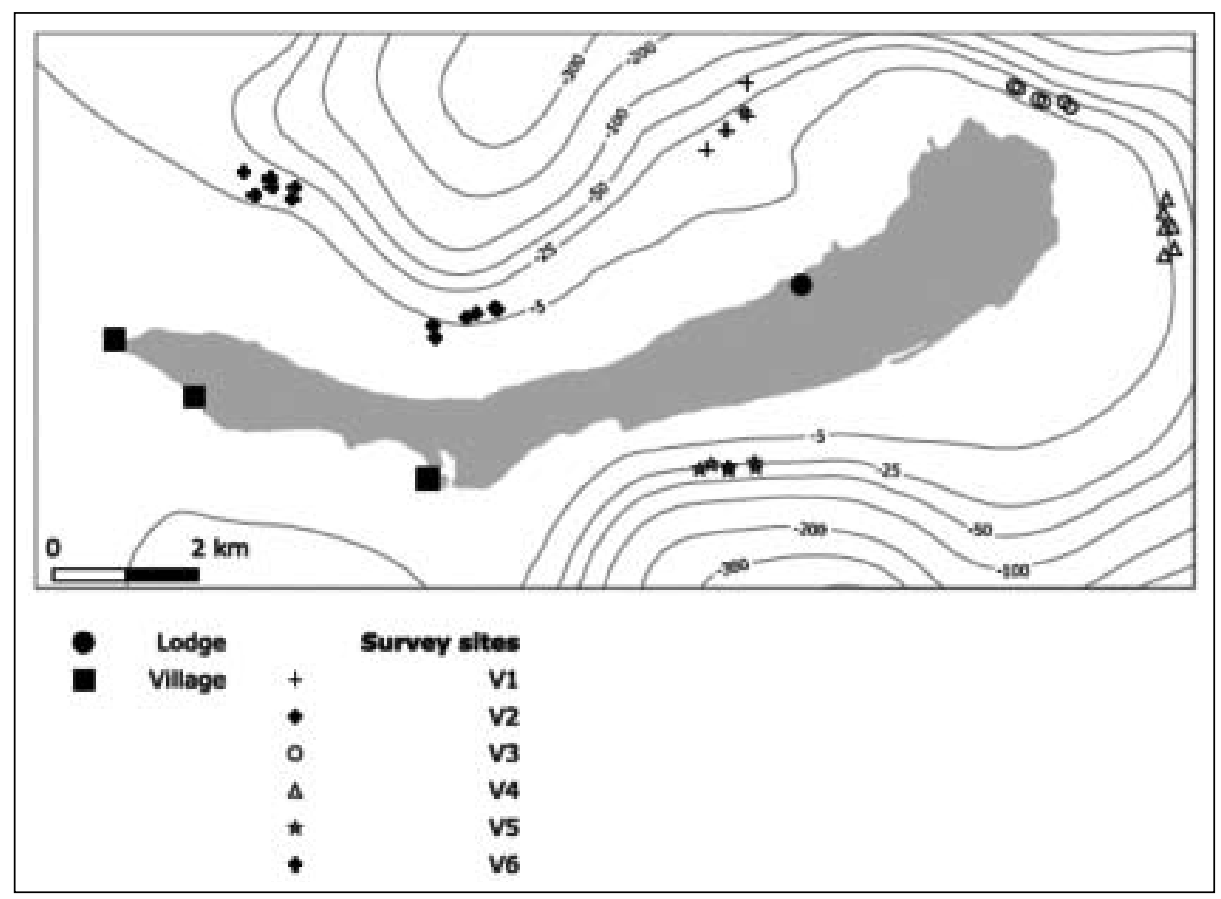

Fig. 2. Location of survey sites around Vamizi Island 
Seasonal changes in wind patterns mean that the south side of Vamizi Island is exposed to the southeasterly monsoon from March to September (Kusi), and the northern side exposed to the northerly monsoon from October to February (Kaskazi). Severe storms from the Mozambique Channel are the main natural physical threat to the integrity of the coral reef communities. There is an average of 3.1 tropical storms annually in the Mozambique Channel (Rodrigues et al., 2000). However, most of these occur to the south of Vamizi, with no serious tropical storms in this area over the last half century.

At a larger scale, Vamizi island lies just where the South Equatorial Current divides and turns south into the Mozambique Current and north into the East African Coastal Current (Saetre \& da Silva, 1984; Rodrigues et al., 2000). Water movement is continuous through the island complexes surrounding Vamizi Island, with a tidal range of $3-4 \mathrm{~m}$. Few large rivers mean that the sediment load of the water is low, although parts of Vamizi reef are regularly exposed to higher sediment loads of outgoing tides that move sand in and out of the lagoon.

\section{Survey methods}

Marine surveys systematically covered the coral reef surrounding Vamizi between 30th October and $21^{\text {st }}$ November 2006. The objective of this survey was to provide information on the distribution and status of marine resources around Vamizi Island for management purposes, and to establish a baseline for monitoring the effects of ensuing management activities.

Manta tow surveys, as described by English et al.(1997) were conducted along the full extent of the Vamizi reef to provide a broad-scale overview of the main features of the benthic community surrounding Vamizi Island. Each observation consisted of a twominute tow at constant speed. Hard coral cover was placed into categories of $0-5$ (table 1 ). These methods have been shown to be relatively insensitive to biases among different observers (Miller \& De'ath, 1995) and capable of discriminating among different benthic assemblages (Done, 1982).

Six locations (Figure 2) were then intensively surveyed where representative coral reef
Table 1: Categories for estimates of \% cover of benthic communities for manta tow and REA surveys (after English et al., 1997) and relative abundance categories for coral species (after DeVantier et al., 1998)

\begin{tabular}{ccl}
\hline Category & \% cover estimate & $\begin{array}{c}\text { Relative abundance } \\
\text { category }\end{array}$ \\
\hline 0 & $0 \%$ & Absent \\
1 & $1-10 \%$ & Rare \\
2 & $11-30 \%$ & Uncommom \\
3 & $31-50 \%$ & Common \\
4 & $51-75 \%$ & Abundant \\
5 & $76-100 \%$ & Dominant \\
\hline
\end{tabular}

communities existed. These locations were stratified along gradients of distance to the fish landing sites and the physical gradients of east to west and north side and south side. At each location surveys were conducted at three replicate sites at each of two depths; shallow (2-3m below the reef crest) and deep (6-8m below the reef crest). At each site and each depth, coral and fish communities were assessed.

Coral communities and threats to coral were assessed using rapid ecological assessment (REA) according to DeVantier et al. (1998) and Scuba search (see Miller, 2003) at each site. During REA, species presence and their relative abundance, and cover of habitat types were estimated visually on a categorical scale (table 1) for deep and shallow locations. Average cover of live hard coral, soft coral and dead coral with algae was calculated for each site from the midpoint of each category (after DeVantier et al., 1998). Scuba search was conducted along three $50 \mathrm{~m}$ transects laid down for the fish density surveys (see below) at each site and depth. For each transect, an area of $50 \times 2 \mathrm{~m}$ $\left(100 \mathrm{~m}^{2}\right)$ was searched for the presence of Crownof-Thorns Starfish (COTS, Acanthaster planci), and the number of coral colonies damaged or killed by Drupella spp and anchor damage was recorded (Miller, 2003).

Fish densities were assessed using underwater visual census (UVC) as described by English et al. (1997). Densities of all non-cryptic species of fish over $5 \mathrm{~cm}$, and excluding pomacentrids, were recorded by species along each of three replicate transects at each site measuring $50 \times 5 \mathrm{~m}\left(250 \mathrm{~m}^{2}\right)$. All counts were conducted by one observer. Results from the three replicate transects were averaged 
to produce an estimate of density at each site for each family. The acanthurid grouping includes Zanclus cornutus. Lutjanid, lethrinid, haemulid and groupers were analysed in one group, named for the purposes of this report as "carnivores".

Fish densities were compared between three groups of sites based on their distance to fishing villages. Far sites are 11.3 and $12.6 \mathrm{~km}$ (V3 and V4 respectively) from the fishing villages. Medium sites are 6.3 and $7.1 \mathrm{~km}$ (V5 and V1 respectively). Close sites are 2.8 and $2.9 \mathrm{~km}$ (V2 and V6 respectively). Densities were log transformed to normalise the data, and ANOVA conducted to determine differences in fish densities with distance from fishing villages.

The 2006 survey was preceded by some preliminary investigations of the marine resources around Vamizi in August 2001 and June 2003. The challenging logistics of the area and the methods used at the time meant that the data collected was not as detailed as 2006. The 2001 survey consisted of two weeks of snorkel surveys. These surveys involved a swim from the beach directly towards the reef crest and aimed to reach the reef, although in some cases this was not possible due to the distances involved and lack of boat support. These snorkel surveys were conducted at regular intervals of $2 \mathrm{~km}$ around the island. In June 2003, two of the six 2006 locations were surveyed (V6 and V1) using the underwater survey methods described above. Timed dives $(1 \mathrm{hr})$ were also conducted at each location to record the presence of fish and coral species.
A list of fish and coral species was compiled from all surveys, including fish species recorded as caught on Vamizi Island reefs during a fisheries monitoring programme in July 2003 (Garnier, 2003).

\section{RESULTS}

\section{Coral habitat}

The manta tow survey along the entire length of the reef showed a high degree of hard coral cover, with a median live hard coral cover of category 2 (11$30 \%$, figure 3 ). The REA results indicated similarly high cover, with an average live hard coral cover of $37 \%$ (range $22-63 \%, n=12$ ). Levels of injury and death of corals at most sites were extremely low ( $\leq 10 \%$ cover of dead corals and $<15 \%$ injury on living corals), and dead coral with algae formed a smaller proportion of cover than hard corals in all sites. Scuba search revealed 11 COTS and 30 colonies with signs of anchor damage across all surveys (a total of $10,800 \mathrm{~m}^{2}$ of reef surveyed). Less than 20 coral colonies were affected by Drupella spp at each of the six locations surveyed around the island (surveys at each location covered a total of $1,800 \mathrm{~m}^{2}$ of reef).

There were no signs of bleaching mortality on the northern and eastern sides of the island. A small number of dead Acropora tabulate corals among a

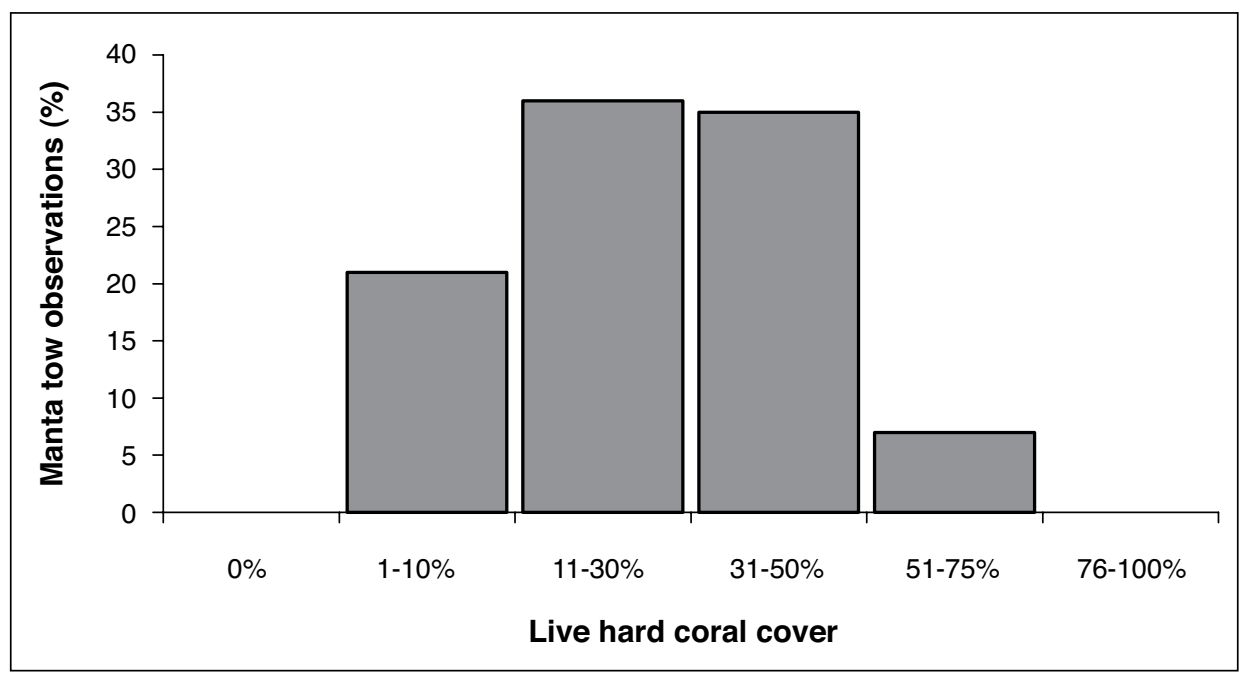

Fig. 3. Histogram of live hard coral cover around Vamizi Island from manta tow surveys $(\mathrm{n}=173)$ 
higher proportion of live Acropora tabulates at one shallow site on the south side of the island (V5, figure 2) suggest a limited amount of bleaching at this site alone, followed by recovery. This was also noted during the manta tow survey (Davidson et al., 2007), and corresponds with anecdotal evidence from snorkel surveys in 2001, when algal dominance on a bleached coral framework was reported only on the reef crest of this area. Hard coral cover has not changed for V6 and V1 since the surveys were completed in these locations in 2003 (Davidson et al., 2007), suggesting there was little effect of the 2004 bleaching event (Obura et al., 2004).

One hundred and eighty three scleractinian coral species from 46 genera and 14 families have been identified from the reefs of Vamizi. Diversity of hard corals averaged 90 species at each location (range 76-114 species), being highest at V6 and lowest at the more exposed V4 on the eastern end of the island. In each location and depth an average of $45 \%$ (range $23-61 \%, n=12$ ) of coral species had an abundance greater than category 2 (i.e. they were categorised as common, abundant or dominant), demonstrating that none of the locations were dominated by small numbers of species.

\section{Reef fish}

In total, 400 species of fish have been recorded for the waters around Vamizi Island, of which 373 are reef-associated fish. Table 2 shows the diversity of species for major family groups.

The majority of interesting variation in densities occurred in the deeper sites, which were located 6-8m below the reef crest on the reef slope. Although we were not able to correlate fish densities with benthic habitat, densities of the most abundant family groups in these deep sites showed strong patterns when plotted against distance from fishing villages (figure 4a). The carnivore group, acanthurids, balistids and chaetodontids all showed higher abundance at the far sites. Labrids showed no effect of distance, and scarids showed lower densities at far sites (figure 4a). Shallow sites tended to be dominated by small species as they were in very shallow water on the reef flat and exposed to wave action. These shallow sites generally showed higher levels of variation within sites than between sites (figure $4 b$ ).
Table 2: Species richness of main reef fish families for Mozamique and for Vamizi

\begin{tabular}{lcc}
\hline Family & $\begin{array}{c}\text { Mozambique } \\
\text { (Pereira, 2000) }\end{array}$ & $\begin{array}{c}\text { Vamizi } \\
\text { reefs }\end{array}$ \\
\hline Acanthuridae & $31 \mathrm{spp}$ & $31 \mathrm{spp}$ \\
Balistidae & $16 \mathrm{spp}$ & $12 \mathrm{spp}$ \\
Chaetodontidae & $23 \mathrm{spp}$ & $21 \mathrm{spp}$ \\
Haemulidae & $15 \mathrm{spp}$ & $10 \mathrm{spp}$ \\
Labridae & $67 \mathrm{spp}$ & $52 \mathrm{spp}$ \\
Lethrinidae & $19 \mathrm{spp}$ & $16 \mathrm{spp}$ \\
Lutjanidae & $22 \mathrm{spp}$ & $10 \mathrm{spp}$ \\
Mullidae & $14 \mathrm{spp}$ & $12 \mathrm{spp}$ \\
Pomacanthidae & $12 \mathrm{spp}$ & $11 \mathrm{spp}$ \\
Pomacentridae & $45 \mathrm{spp}$ & $35 \mathrm{spp}$ \\
Scaridae & $24 \mathrm{spp}$ & $20 \mathrm{spp}$ \\
Serranidae & $56 \mathrm{spp}$ & $31 \mathrm{spp}$ \\
Totals & 344 & 261 \\
\hline
\end{tabular}

There were very high concentrations of fish at one location that could not be included in the UVC surveys due to strong currents and the nature of the site. Here there were large aggregations of $100+$ gray reef sharks (Carcharhinus amblyrhyncos) and many species of grouper, snapper and emporer. Snappers and emporers were present in large schools too abundant to attempt to estimate numbers. Large individuals ( $>1 \mathrm{~m}$ total-length) of Epinephalus lanceolatus and Epinephalus tukula were observed, as were Napolean wrasse (Cheilinus undulates). Trevallies were seen in abundance, together with individuals of other top predators such as dogtooth tuna (Gymnosarda unicolor). The area is a long way from fishing villages, extremely exposed to weather and has very strong and unpredictable currents. The large aggregations of piscivores attract significant attention from the Maluane lodge for diving purposes, albeit for experienced divers only, and have been the cause of two newspaper articles by a well known diving journalist and writer claiming it to be "one of the healthiest underwater landscapes I have ever seen" (Ecott, 2006; 2007).

\section{DISCUSSION}

\section{Diversity and condition of coral and reef fish communities}

There have been no reported studies of the northern Quirimbas Archipelago previous to those initiated 


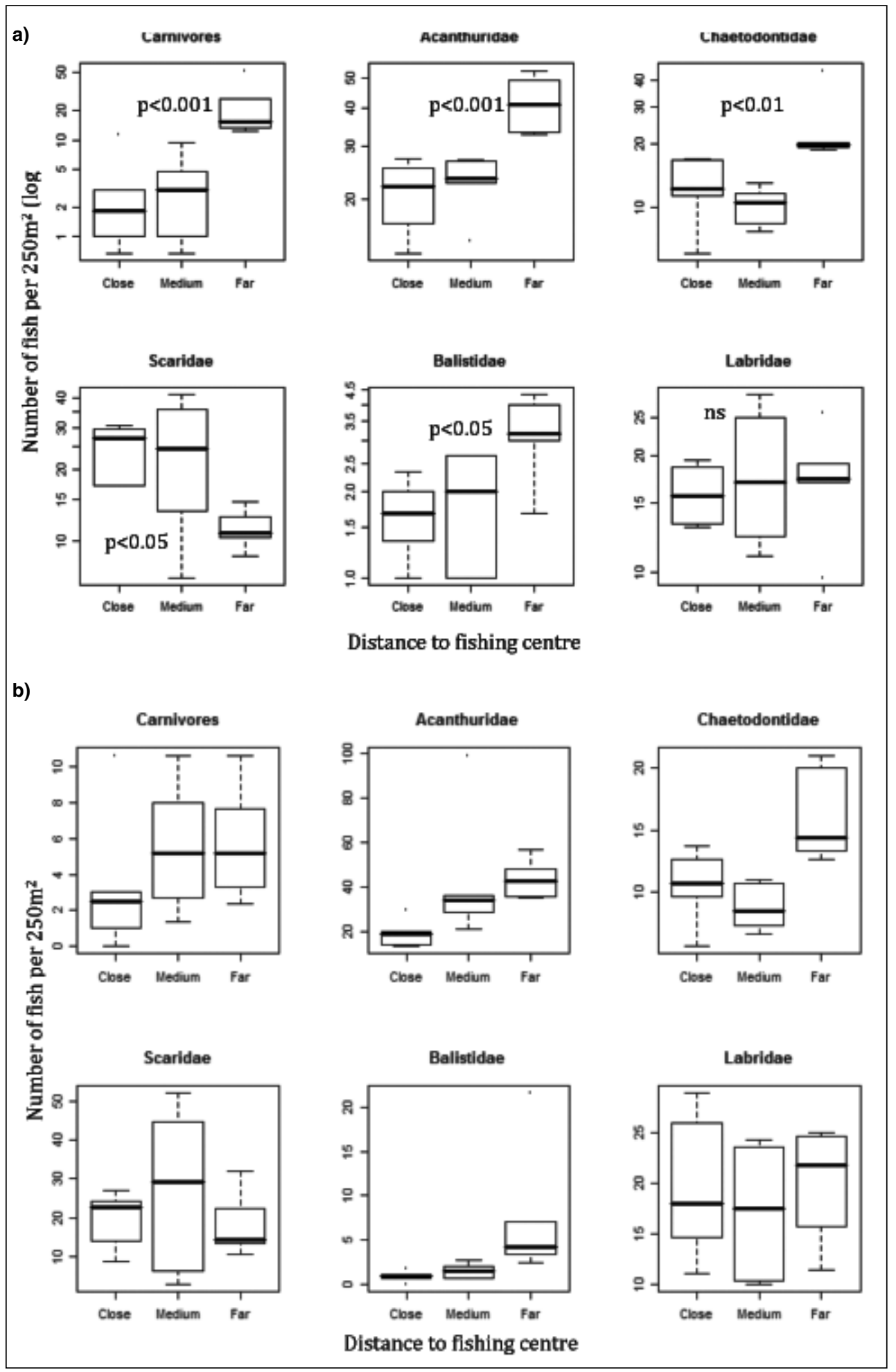

Fig. 4. Fish density (number of fish per $250 \mathrm{~m}^{2}, \mathrm{n}=6$ ) by family group against the distance to fishing villages for (a) deep sites and (b) shallow sites. Far sites are 11.3 to $12.6 \mathrm{~km}$ from the fishing villages, medium sites are 6.3 to $7.1 \mathrm{~km}$ distant and close sites are 2.8 to $2.9 \mathrm{~km}$ distant 
by ZSL and Maluane, so this report goes some way to filling that gap by providing information from Vamizi Island's reef.

Biological diversity of corals and reef fishes around Vamizi Island is high relative to results reported from other studies in Mozambique. The 46 genera of corals recorded around Vamizi compares favourably to the "best reefs in Mozambique" in the Primeiras and Segundas Archipelago where 43 coral genera were identified (Muthiga et al., 2008). Previous long-term studies from the southern Quirimbas Archipelago have generated a list of 375 species of reef fish (Pereira, 2000; Whittington et al., 1998), compared to the 373 species that have been recorded around Vamizi alone. The species list is not yet complete for Vamizi, as species were still being added at the end of the 2006 survey; some remain unidentified; and small and cryptic species such as gobies ( 4 species recorded) and blennies ( 3 species recorded) are certainly under-represented with minimal effort yet focused on them. However, it seems that many of the species of the main reef fish families that are recorded for Mozambique are represented on Vamizi reef (table 2).

It has been noted elsewhere that the diversity of fishes in southern Africa decreases southwards due to the subtropical subtraction effect resulting from decreasing temperatures as the Mozambican Current flows southwards, and the absence of reefs in the central section of Mozambique (Pereira, 2000; Turpie et al., 2000). This decrease in diversity is demonstrated by the relatively high diversity in the Quirimbas compared to the 197 species of reef fish recorded for the Primeiras and Segundas Archipelago (Muthiga et al., 2008). Given the location close to where the South Equatorial Current divides into the southern flowing Mozambican Current the area may play an important strategic location for marine conservation, potentially acting as a source of larval supply.

This strategic importance may not be limited solely to species diversity. Many areas in Mozambique and Tanzania have suffered extensive bleaching from the 1997/98 bleaching event (Linden et al., 2002), in particular the north of Mozambique where bleaching was up to $99 \%$ (Motta et al., 2000), and again in 2004 (Obura et al.,2004). The average coral cover estimate of $37 \%$ from all REA locations compares favourably with surveys elsewhere in the Quirimbas Archipelago (35\%, Obura, 2002) to indicate good condition. No evidence of extensive bleaching mortality was observed around Vamizi Island, with only some limited evidence of bleaching mortality on the south side of the island and good signs of recovery. This indicates that the area may either have suffered limited localised mortality, or that there has been extremely rapid recovery. The high diversity and structure of the reef suggest that the former explanation is most likely.

West and Salm (2003) list several environmental factors that help mitigate the effects of thermal bleaching including: mixing of cooler waters, upwelling, and proximity to cooler deep water; currents and tidal range. Surviving communities become the source of larval supply during recovery of other, denuded, coral reef communities. No sources of information were obtained for water temperature and quality of the area. However, the low level of bleaching and proximity to deep water may suggest some thermal protection, and the distance from any major source of pollution and sedimentation (the nearest major river being the Rovuma river, figure 1) indicate good environmental conditions. Proximity to strong currents and deep water, particularly on the north and east side of the island, may provide some thermal protection to the reefs.

Overfishing is a significant threat in East Africa (Obura, 2002), and is a hindrance to the recovery of reefs from bleaching (Muthiga et al., 2008). Fishing is known to reduce the biomass of reef fish, in particular invertebrate feeding fishes and carnivores (Jennings \& Polunin, 1996). Herbivores are also depressed by fishing, which is an important factor in the resilience and recovery of coral reefs from bleaching events (Marshall \& Schuttenberg, 2006). Studies on the recovery of fish densities have shown that acanthurids, balistids, and lutjanids increase following protection whilst scarid densities decrease (McClanahan et al., 2007). It is difficult to make direct comparisons with studies from other sites in the region due to problems with controlling for sources of variation. However, patterns of abundance around Vamizi appear to be consistent with decreasing levels of fishing pressure further from fishing villages, and densities of fish families observed in this study correspond well with those 
found in parks that had been protected from fishing for ten years or more (e.g. McClanahan et al., 2007). Whilst this comparison is only tentative, given the lack of comparable published figures for nearby areas it serves to show that there are higher densities of reef fish in the sites at the east end of Vamizi than may be expected considering the lack of formal protection from fishing. Whilst there may be some environmental factors that influence this result, we hypothesise that this is primarily because fishing pressure in these areas is reasonably low, so they have acted as a natural refuge for fish.

Anecdotal evidence supports the hypothesis that fishing pressure is low at the east end of the island. Very few boats are observed fishing in that area, with the majority clustered reasonably close to the landing sites for the villages (Hill, personal observation 2002-2006), and technology is low as indicated by the lack of motorised boats until 2006. The remote nature of Vamizi from markets and urban centres may have played a part in limiting fishing technology development, and it has been shown elsewhere that distances to markets influence level of exploitation (Cinner \& McClanahan, 2006). The closest urban settlements are in Tanzania, but navigation from these towns to Vamizi is treacherous. Market linkages therefore seem to be limited as demonstrated by the lack of a market for fresh fish (see site description). As the sites furthest from the fishing villages involve a long journey in the exposed areas outside of the lagoon, and as the eastern end of the island is exposed to strong currents and has no protection from wind or waves, fishing with such low technology may have been limited to the most intrepid fishers and to times with good weather conditions. This protection may have been more limited prior to the establishment of Maluane in 2002 as fishermen could make temporary camps on beaches at the eastern end of the island which is now occupied by the lodge. But even then, weather and exposure combined with poor technology probably still prevented much fishing. However, as technology and access to markets starts to improve, this relatively "protected" status may change rapidly.

Sharks, rays and large groupers are present, but are not commonly seen in the main survey areas (with the exception of the one site commented on by Ecott, $2006 \&$ 2007). As even low levels of fishing effort are known to affect fish community structure (Jennings \& Polunin, 1996), it may not require much fishing effort to result in such low abundances. However, the presence of the gray reef shark aggregation at the site commented on by Ecott (2006 \& 2007) may indicate that this site is as close as possible to an example of an unfished reef. On this reef, currents are strong and appear to be unpredictable, making it a diving destination only for the most experienced divers, and it is exposed to weather from all directions. These features may well have prevented any substantial fishing activity with traditional gear and boats. All species groups that may be expected in a healthy reef system were present in large numbers, and many snappers and emporers appeared to be forming large aggregations. Large fish aggregations are widely recognised as ecologically important but vulnerable to overexploitation (Claydon, 2004; Sadovy $\&$ Domeier, 2005). Their continued presence therefore indicates limited fishing activity. More research will be required to explore the function of these aggregations found near Vamizi, and their temporal presence.

Although work in this area is in its early stages and still relatively exploratory, the general pattern shown by these results suggests that the area could have high strategic importance for the region. It has been naturally "protected" from overexploitation, probably because of its isolation by distance from urban centres and major sources of pollution. It also appears to have been either protected from or have some level of resilience to previous mass-bleaching events.

These facts taken as a whole are important because, at the time of the survey, Vamizi and nearby reefs may be some of the closest examples of "natural" reefs that remain along the East African coastline. Elsewhere in Mozambique and East Africa, reefs have experienced severe degradation from anthropogenic and natural causes (Motta et al., 2000; Obura et al., 2004) and are at best in a state of recovery. Given their high representation of Mozambican marine diversity, their location at the northern end of the Mozambican Current and their relatively natural condition, they may have an important strategic location for marine conservation within the country. The importance of protecting remote reefs that have escaped overexploitation and 
could act as a source of replenishment for degraded reefs is well recognised (Wilkinson, 2008).

\section{Conservation challenges}

Whilst Vamizi has remained isolated from markets historically, improvements in the political stability of Mozambique, technological development, and dwindling resources and increasing coastal population pressure across the whole of East Africa are likely to change this situation rapidly. Immigration to the area and technological development is already occurring (see site description), which will place increasing demands and pressures on the marine resources. Such a pattern has already been seen in the southern part of the Quirimbas Archipelago (Whittington et al.,1998). As noted elsewhere, increasingly destructive fishing equipment may accompany this immigration (Mangi \& Roberts, 2006).

Timely management is therefore required to manage these changes. Maluane has started to act on this need by undertaking the necessary scientific investigations on the resource base and on resource users and by supporting the establishment of community-based natural resource management committees (Garnier et al., 2008). Acting on the results of the scientific surveys that have been conducted, the communities have decided to implement a large no-take zone around the eastern end of the island. Maluane has provided some logistical and financial assistance to help the communities to enforce this area. This decision by the communities was taken not just as a result of increasing pressure on fisheries resources, but also because of the importance of the area for turtle conservation, following a community-based turtle project that has been running with Maluane since 2002. However, the difficulty of maintaining such co-management systems in the face of high levels of immigration and associated population increases and cultural heterogeneity will represent a real challenge to the sustainability of these conservation efforts as has been found elsewhere (Pollnac et al., 2001).

Management action is also essential to secure the tourism potential for the future. Tourism can potentially be a very valuable non-extractive use of coral reefs with most divers prepared to pay for access to well protected reefs (Arin \& Kramer, 2002). Maluane has already started to show the tourism value of the marine resources to the area with the high price of their holiday product and conservation bed levy (see site description). Protection of these resources will assist in the long-term development of the area through the sustainability of this tourism revenue. However, tourism itself can be a potential source of pollution and environmental damage through poor construction and waste management activities, and poor diving practices (Barker \& Roberts, 2004; Worachananant et al., 2008). It can also cause social damage in nearby communities (Thiele et al., 2005). Maluane and other tourism operations in the Quirimbas must therefore manage their operations carefully with sensitivity to these considerations, and in close cooperation with communities.

It has been noted recently that the Quirimbas also holds potentially valuable stores of oil and gas, which could be a great boon to the Mozambican economy. Whilst the financial gains of oil and gas extraction represent an important opportunity to the country, it is essential to consider the potential long-term gains that can continue to be obtained from tourism if oil and gas extraction is carefully and appropriately planned, with scientific inputs and monitoring, and environmental impacts appropriately mitigated. The importance of the contribution sustainable fisheries makes, and could continue to make, to local livelihoods and development should also be a key factor in the decision of how to manage these resources (Gameiro \& Wilson, 2003; Walmsley et al., 2006). This is especially important given that fish provides a significant source of animal protein in local diets (Walmsley et al., 2006), and that degradation of marine resources represents a potential threat to people's livelihoods (Payet \& Obura, 2004). It is hoped that the value of these reef resources remains of central importance to the regional and national governments and that protection for sustainable use is vigorously applied for the benefit of future generations of Mozambicans.

\section{CONCLUSION}

This paper helps to fill the gap in knowledge of the coral reef resources in the northern Quirimbas 
Archipelago, Mozambique, by providing information on coral and fish communities around Vamizi Island. Underwater surveys in the area suggest that the reefs of Vamizi could have a high strategic conservation importance for Mozambique and the region. They have been naturally "protected" from over-exploitation, probably because of their isolation from urban centres and major markets. The reefs appear to have been either protected from or have some level of resilience to previous massbleaching events. Given the location of the northern Quirimbas Archipelago at the northern end of the Mozambique current, there is potential for this historical refuge from anthropogenic and climatic stressors to act as a source of replenishment for reefs to the south that have been affected by bleaching, flooding and overfishing. However, high levels of immigration, rapidly increasing populations, improved access to markets and technology, and potential oil and gas exploitation pose significant and unprecedented threats to the area. Government, conservation organisations and tourism operations in the area have an important responsibility in assisting the sustainable development of the area and championing marine conservation in close collaboration with local communities.

Acknowledgements - The authors would like to thank Maria Irene Augusto and Rachide Dade for their constant and invaluable assistance to the research team in the field, Christopher Cox, cofounder of Maluane project, as well as local and provincial authorities, including representatives from the Ministry of Environment (MICOA). This study has been jointly funded by the Zoological Society of London, private donors and the Maluane project. Thanks to Jose Paula (Transmap) for assistance with the maps. Thanks to Marcus Rowcliffe, two anonymous reviewers and the Editors for their comments on earlier versions of this manuscript.

\section{REFERENCES}

Arin, T. \& Kramer, R.A. (2002) Divers' willingness to pay to visit marine sanctuaries: an exploratory study. Ocean \& Coastal Management 45: 171183.

Barker, N.H.L. \& Roberts, C.M. (2004) Scuba diver behavioiur and the management of diving impacts on coral reefs. Biological Conservation 120: 481-489

Béné, C. (2003) When fishery rhymes with poverty: a first step beyond the old paradigm on poverty in small-scale fisheries. World Development 31: 949-975.

Cinner, J. E., \& McClanahan, T.R. (2006) Socioeconomic factors that lead to overfishing in small-scale coral reef fisheries of Papua New Guinea. Environmental Conservation 33: 73-80.

Claydon, J. (2004) Spawning aggregations of coral reef fishes: characteristics, hypotheses, threats and management. Oceanography and Marine Biology 42: $265-302$.

Davidson, J., Hill, N.A.O., Muaves, L., \& Mucaves, S. (2007) Assessment of fish and coral community biodiversity and health, and recommendations for marine resource management. Vamizi Island marine ecological assessment, October 2006. Unpublished report. Zoological Society of London and Cabo Delgado Biodiversity and Tourism Project, London.

DeVantier, L.M., De'ath, G., Done, T.J. \& Turak, E. (1998) Ecological assessment of a complex natural system: a case-study from the Great Barrier Reef. Ecological Applications 8: 480-496.

Done, T.J. (1982) Patterns in the distribution of coral communities across the central Great Barrier Reef. Coral Reefs 1: 95-107.

Ecott, T. (2006) Easy on Vamizi. 18th March 2006. The Guardian, UK. http://www.guardian.co.uk/ travel/2006/mar/18/mozambique.ecotourism. hotels?page $=$ all (accessed 27th February 2008).

Ecott, T. (2007) Diving the coral reefs of Mozambique. 3rd February 2007. TimesOnline, UK. http:// travel.timesonline.co.uk/tol/life_and_style/ travel/destinations/africa/article1315343.ece (accessed 27th February 2008).

English, S., Wilkinson, C. \& Baker, V. (1997) Survey manual for tropical marine resources. Australian Institute of Marine Science, Townsville, Australia.

Gameiro, M.F.S. \& Wilson, J.D.K. (2003) The importance of marine fisheries to coastal community livelihoods in SADC countries (Mozambique, South Africa, Tanzania, Angola \& Namibia), final report. Kusi Limitada Consultores, Maputo, Mozambique.

Garnier, J. (2003) Report for the Marine Programme, Cabo Delgado Biodiversity and Conservation Project, November 2003. Unpublished report. Zoological Society of London / Cabo Delgado Biodiversity and Tourism Project, Pemba, Mozambique.

Garnier, J., Silva, I., Davidson, J., Hill, N., Muaves, L., Mucaves, S., Guissamulo, A. \& Shaw, A. 
(2008). Co-Management of the Reef at Vamizi Island, Northern Mozambique. In: Obura, D.O., Tamelander, J., \& Linden, O. (eds.). Ten years after bleaching - facing the consequences of climate change in the Indian Ocean. Cordio Status Report 2008. Coastal Oceans Research and Development in the Indian Ocean /Sida-SAREC. Mombasa. htpp//:www.cordioea.org. Pp. 121-128.

Hill, N. (2005) Livelihoods in an artisanal fishing community and the effect of ecotourism. MSc thesis, Imperial College London, University of London, UK.

Jennings, S. \& Polunin, N.V.C. (1996) Effects of fishing effort and catch rate upon the structure and biomass of Fijian reef fish communities. Journal of Applied Ecology 33: 400-412.

Linden, O., Souter, D., Wilhelmsson, D. \& Obura, D. editors. (2002) Coral Reef Degradation in the Indian Ocean. Status report 2002. CORDIO, Kalmar, Sweden.

Loper, C., Pomeroy, R., \& Hoon, V. (2008) Socioeconomic conditions along the world's tropical coasts: 2008. Global Socioeconomic Monitoring Initiative (SocMon).

Mangi, S.C., \& Roberts, C.M. (2006) Quantifying the environmental impacts of artisanal fishing gear on Kenya's coral reef ecosystems. Marine Pollution Bulletin 52: 1646-1660.

Marshall, P. \& Schuttenberg, H. (2006). A reef manager's guide to coral bleaching. Great Barrier Reef Marine Park Authority, Townsville, Australia.

McClanahan, T.R., Graham, N.A.J., Calnan, J.M. \& McNeil, M.A. (2007) Toward pristine biomass: reef fish recovery in coral reef marine protected areas in Kenya. Ecological Applications 17: 1055-1067

Miller, I. R. (2003) Crown-of-thorns starfish and coral surveys using the manta tow and scuba search techniques: Standard Operational Procedure, Number 8.Australian Institute of Marine Science, Townsville, Australia.

Miller, I. \& De'ath, G. (1995) Effects of training on observer performances in assessing benthic cover by means of the manta tow technique. Marine and Freshwater Research 47: 19-26.

Motta, H., Rodrigues, M.J. \& Schleyer, M.H. (2000) Coral reef monitoring and management in Mozambique. In: Souter, D., Obura, D. \& Linden, O. (eds.). Coral reef degradation in the Indian ocean: status report 2000. CORDIO, Stockholm. Pp. 43-48.

Muthiga, N., Costa, A., Motta, H., Muhando, C., Mwaipopo, R. \& Schleyer, M. (2008) Status of coral reefs in Eastern Africa: Kenya, Tanzania, Mozambique and South Africa. In: Status of coral reefs of the world: 2008 Wilkinson, C. (ed.). Global Coral Reef Monitoring Network and Reef and Rainforest Research Centre, Townsville, Australia. Pp. 91-104.

Ngoile, M.A.J. \& Linden, O. (1997) Lessons learned from Eastern Africa: the development of policy on ICZM at national and regional levels. Ocean \& Coastal Management 37: 295-318.

Obura, D. (2002) Status of coral reefs in Eastern Africa: Kenya, Tanzania, Mozambique and South Africa. In: Status of coral reefs of the world: 2002 Wilkinson, C. (ed.). Australian Institute of Marine Science, Townsville, Australia. Pp. 63 - 73.

Obura, D., Church, J., Daniels, C., Kalombo, H., Schleyer, M. \& Suleiman, M. (2004) Status of coral reefs in East Africa 2004: Kenya, Tanzania, Mozambique and South Africa. In: Status of coral reefs of the world: 2004. Wilkinson, C. (ed.). Australian Institute of Marine Science, Townsville, Australia. Pp. 171-188.

Payet, R. \& Obura, D. (2004) The negative impacts of human activities in the Eastern African region: An international waters perspective. Ambio 33: 24-33.

Pereira, M.A.M. (2000) A review of the ecology, exploitation and conservation of reef fish resources in Mozambique. In: 2nd National Conference on Coastal Zones Research, Maputo, Mozambique.

Pereira, M.A.M., Videira, E.J.S., Motta, H., Louro, C.M.M., Abrantes, K.G.S. \& Schleyer, M.H. (2003) Coral reef monitoring in Mozambique. III: 2002 report. Mozambique Coral Reef Management Programme. MICOA/CORDIO/ WWF, Maputo, Mozambique.

Pollnac, R.B., Crawford, B.R. \& Gorospe, M.L.G. (2001) Discovering factors that influence the success of community-based marine protected areas in the Visayas, Philippines. Ocean \& Coastal Management 44: 683-710.

Rodrigues, M., Motta, H., Whittington, M.W. \& Schleyer, M.H. (2000) Coral reefs in Mozambique. In: McClanahan,T.R., Sheppard, C.R.C. \& Obura, D. (eds.). Coral reefs of the Indian Ocean: Their ecology and conservation. Oxford University Press, New York. Pp. 107-129.

Sadovy, Y. \& Domeier, M. (2005) Are aggregationfisheries sustainable? Reef fish fisheries as a case study. Coral Reefs 24: 254-262.

Saetre, R. \& da Silva, A.J. (1984) The circulation of the Mozambique Channel. Deep Sea Research 31: 485-508.

Thiele, M.T., Pollnac, R.B. \& Christie, P. (2005) Relationships between coastal tourism and ICM sustainability in the central Visayas region of the Philippines. Ocean \& Coastal Management 48: 378-392. 
Tobey, J. \& Torrell, E. (2006) Coastal poverty and MPA management in mainland Tanzania and Zanzibar. Ocean \& Coastal Management 49: 834-854

Turpie, J. K., Beckley, L.E. \& Katua, S.M. (2000) Biogeography and the selection of priority areas for conservation of South African coastal fishes. Biological Conservation 92: 59-72.

Walmsley, S., Purvis, J. \& Ninnes, C. (2006) The role of small-scale fisheries management in the poverty reduction strategies in the Western Indian Ocean region. Ocean \& Coastal Management 49: 812-833.

West, J.M. \& Salm, R.V. (2003) Resistance and resilience to coral bleaching: Implications for coral reef conservation and management. Conservation Biology 17: 956-968.
Whittington, M.W., António, C.M., Heasman, M.S., Myers, M. \& Stanwell-Smith, D. (1998) Marine biological and resource use surveys of the Quirimba Archipelago. Results summary and management recommendations. Frontier Mozambique Environmental Research Report 6, Society for Environmental Exploration, London and Ministry for the Coordination of Environmental Affairs, Maputo.

Wilkinson, C. (2008) Status of coral reefs of the world: 2008. Global Coral Reef Monitoring Network and Reef and Rainforest Research Centre, Townsville, Australia. 296pp.

Worachananant, S., Carter, R.W., Hockings, M. \& Reopanichkul,P. (2008) Managing the impacts of SCUBA divers on Thailand's coral reefs. Journal of Sustainable Tourism 16: 645-663. 
